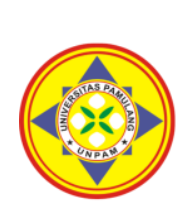
PERKUSS

\title{
PENGARUH KUALITAS PRODUK DAN HARGA TERHADAP KEPUTUSAN PEMBELIAN PADA DISTRIBUTOR TEH BOTOL SOSRO WILAYAH TANGERANG SELATAN
}

\author{
${ }^{1}$ Nurul Sheila Safitri, ${ }^{2 *}$ Nani \\ Universitas Pamulang, Tangerang, Banten, Indonesia \\ *dosen01704@unpam.ac.id
}

\begin{abstract}
Abstrak
Tujuan dari Penelitian ini adalah untuk mengetahui pengaruh kualitas produk terhadap keputusan pembelian Teh Botol Sosro pada mahasiswa Universitas Pamulang. Untuk mengetahui pengaruh harga terhadap keputusan pembelian Teh Botol Sosro pada mahasiswa Universitas Pamulang. Untuk mengetahui pengaruh kualitas produk dan harga terhadap keputusan pembelian pada mahasiswa Universitas Pamulang. Penelitian ini menggunakan metode penelitian pendekatan kuantitatif. Populasi yang digunakan yaitu mahasiswa Universitas Pamulang Semester 4 dan 5 periode bulan Mei 2020 - Agustus 2020. Untuk menentukan sampel menggunakan teknik perhitungan Rao Purba dan didapatkan sebanyak 100 responden. Metode pengumpulan data dilakukan dengan penyebaran kuisioner. Pengolahan data menggunakan SPSS versi 22. Metode analisis dalam pengolahan data uji adalah Uji Validitas, Uji Reabilitas, Uji Regresi Linear Sederhana, Uji regresi linear berganda, uji determinasi, dan uji hipotesis parsial (Uji T) dan simultan (Uji F). Berdasarkan Hasil penelitian kualitas produk dapat disimpulkan bahwa Kualitas Produk berpengaruh positif dan signifikan terhadap keputusan Pembelian.
\end{abstract}

Kata Kunci: Kualitas Produk, Harga, Keputusan Pembelian.

\section{Abstract}

The purpose of this study was to determine the effect of product quality on purchasing decisions of bottle sosro tea in pamulang university students. To deterimine the effect of price on purchasing decisions of sosro bottled tea for Pamulang University students. The determine of product quality and price on purchasing decisions of Sosro bottled tea for Pamulang University. This research uses a quantitative approach research method. With the population used namely Pamulang University students Semester 4 and 5 for the period May to August 2020. To determinate the sample using Rao Purba calculation technique and obtained as many as 100 respondents. The data collection method was carried out by distributing questionnaires.

Keywords: Product Quality, Price, and Purchase Decisions

\section{PENDAHULUAN}

Pada zaman sekarang ini dunia bisnis dan industri bergerak semakin ketat dan pesat, oleh karena itu peran perusahaan dalam mengelola usahanya butuh ide dan penguasaan yang cemerlang untuk mengupgrade produk yang mereka keluarkan dari waktu ke waktu. Salah satu yang mengalami perkembangan pesat saat ini adalah makanan dan minuman. Industri makanan dan minuman ini tidak hanya memiliki prospek yang baik tetapi ini juga menjadi indikasi bahwa persaingan antara makanan minuman ini sangatlah ketat, inilah yang dapat disebabkan dari pertumbuhan industri manakan minuman mengalami kenaikan yang signifikan.

Menurut Airlangga Hartarto (Menteri Perindustrian), mengatakan peran sektor makanan dan minuman terlihat dari kontribusinya yang konsisten dan signifikan terhadap produk domestik bruto industri non- minyak dan gas serta peningkatan realisasi investasi. Kementerian Perindustrian mencatat sumbangan industri makanan dan minuman terhadap produk domestik bruto industri non migas mencapai $34,95 \%$ pada triwulan ketiga 2017. Hasil itu menjadikan sektor makanan dan minuman menjadi 
kontributor terbesar dibanding subsektor lain. Selain itu, pencapaian tersebut mengalami kenaikan $4 \%$ dibanding periode yang sama pada 2016. Sedangkan kontribusinya pada triwulan ketiga 2017 sebesar $6,21 \%$ atau naik 3,85\% dibanding periode yang sama pada tahun sebelumnya.

Minuman Teh dalam kemasan menjadi minuman kemasan terlaris di Indonesia setelah air minum. Hal Ini disimpulkan karena berdasarkan porsinya, industri minuman teh dalam kemasan mengambil sekitar 5,7\% dari total industry minuman ringan yang ditaksir mencapai 35 miliar liter per tahun. Disusul minuman susu (dairy) (3,1\%), minuman jus (3\%), minuman karbonasi $(2,5 \%)$, serta sisanya minuman isotonic, kopi, dan energi. Di posisi pertama ada air minum (gallon dan AMDK) yang mengambil porsi hingga $70 \%$.

PT. Sinar Sosro sebagai salah satu produsen minuman teh siap saji dengan merek produk Teh Botol Sosro, merupakan salah satu perusahaan tertua sekaligus sebagai perusahaan pelopor yang memproduksi minuman teh siap saji yang berbahan dasar teh wangi yaitu percampuran teh hijau dan melati. Sejak Teh Botol Sosro berdiri, eksistensi Teh Botol Sosro sudah tidak dapat diragukan lagi. Dimana Garvin yang dikutip oleh Fandy Tjiptono menyatakan bahwa kualitas produk yang dihasilkan dapat mempengaruhi pangsa pasar, dimana produk yang memiliki kualitas produk lebih tinggi akan disukai sehingga mendapatkan pangsa pasar yang lebih besar. Selain harus mengetahui bentuk proses keputusan pembelian konsumen, perusahaan juga perlu untuk memahami karakteristik konsumen secara umum. Dan juga harus memiliki produk yang berbeda dengan perusahaan lain dalam segi fisik, design atau yang lainnya sehingga konsumen tertarik untuk membeli.

Keputusan pembelian adalah suatu pilihan yang dipilih oleh konsumen setelah membandingkan satu produk dengan produk- produk lainnya. Jika konsumen sudah membuat kesepakatan untuk memutuskan membeli, artinya ada sesuatu yang menarik dari produk itu sendiri sehingga konsumen pasti memilih produk itu sendiri.

\section{TINJAUAN PUSTAKA}

1. Kualitas Produk

Kualitas produk adalah suatu kondisi fisik, sifat, dan fungsi produk, baik itu produk barang atau produk layanan jasa, berdasarkan tingkat mutu yang disesuaikan dengan durabilitas, reliabilitas, serta mudahnya penggunaan, kesesuaian, perbaikan serta komponen lainnya yang dibuat untuk memenuhi kepuasan dan juga kebutuhan pelanggan.

Prawirosentono menjelaskan bahwa kualitas produk adalah suatu ciri khas tertentu dari produk yang mampu memenuhi ekspektasi konsumen.

Dimensi Kualitas Produk

a. Kinerja

Tingkat penilaian kinerja adalah suatu penilaian terkait bagaimana suatu produk bisa disajikan dan juga ditampilkan pada pelanggan. Tingkat penilaiannya akan fokus pada karakteristik dasar dari produk tersebut, contohnya adalah dimensi kinerja dari produk makanan adalah rasa dari makanan itu sendiri.

b. Keandalan

Tingkat keandalan dan juga konsistensi dari suatu produk dalam proses pengerjaan maupun pembuatannya sangat mempengaruhi minat konsumen. Keandalan sangat erat kaitannya dengan minat pelanggan dan bagaimana mendapatkan kepercayaan dari pelanggan.

c. Keistimewaan

Karakteristik sekunder ini hadir sebagai pelengkap dan bisa diartikan sebagai kelengkapan atas berbagai atribut produk yang tersedia pada suatu produk. Di beberapa waktu tertentu, kinerja pada suatu produk akan sesuai dengan pesaingnya, namun yang membedakan adalah fitur yang terkandung di dalamnya. 
d. Kesesuaian

Ciri khas yang berkaitan dengan desain pada suatu produk akan menghasilkan kesesuaian standar yang sebelumnya sudah ditentukan berdasarkan kesepakatan yang ada sebelumnya.

e. Daya Tahan

Daya tahan produk adalah karakteristik yang erat kaitannya dengan berapa lama tingkat ketahanan produk tersebut. Pada produk makanan atau minuman, biasanya akan diartikan dengan tanggal kadaluarsa.

f. Kemampuan Melayani

Dalam hal ini, kemampuan dalam hal melayani berhubungan langsung dengan tingkat kecepatan, kompetensi, dan juga kenyamanan yang bisa diberikan oleh suatu perusahaan kepada pelanggannya yang terkait dengan penanganan jika nantinya ada keluhan pada produk yang diproduksi oleh perusahaan.

g. Estetika

Estetika adalah suatu keindahan pada suatu produk yang berhubungan dengan panca indera, dimana produk tersebut mampu menggambarkan nilai keindahan yang erat kaitannya dengan rasa, desain, aroma

2. Harga Produk

Menurut Peter dan Olson (2000) harga didefinisikan jumlah uang yang harus diserahkan konsumen untuk membeli suatu produk atau jasa. Harga merupakan satusatunya elemen yang berkaitan dengan pendapatan. Menurut Kotler dan Amstrong (2008) harga adalah sejumlah uang yang dibebankan atas produk atau jasa atau jumlah dari nilai yang ditukar konsumen atas manfaat-manfaat karena memiliki atau mengunakan produk atau jasa tersebut.

Kesan konsumen terhadap harga baik itu mahal, murah maupun standar akan berpengaruh aktivitas pembelian selanjutnya dan kepuasan konsumen setelah pembelian. Kesan ini akan menciptakan nilai persepsi konsumen terhadap suatu barang. Manakala konsumen kecewa setalah membeli suatu barang ternyata terlalu mahal menurut konsumen, maka kemungkinan selanjutnya dia akan enggan untuk membeli barang itu lagi dan bisa jadi beralih ke barang lain.

3. Keputusan Pembelian

Keputusan pembelian merupakan pemikiran dimana individu mengevaluasi berbagai pilihan dan memutuskan pilihan pada suatu produk dari sekian banyak pilihan. Menurut Kotler \& Amstrong (2014), keputusan pembelian adalah tahap dalam proses pengambilan keputusan pembeli di mana konsumen benar-benar membeli.

Menurut Schiffman dan Kanuk (2014) keputusan pembelian didefinisikan sebagai sebuah pilihan dari dua tahu lebih alternatif pilihan. Menurut Tjiptono (2012) keputusan pembelian adalah sebuah proses dimana konsumen mengenal masalahnya, mencari informasi mengenai produk atau merek tertentu dan mengevaluasi secara baik masing-masing alternatif tersebut dapat memecahkan masalahnya, yang kemudian mengarah kepada keputusan pembelian.

Dari pengertian tersebut dapat disimpulkan keputusan pembelian merupakan sebuah proses pengambilan keputusan yang diawali dengan pengenalan masalah kemudian mengevaluasinya dan memutuskan produk yang paling sesuai dengan kebutuhan

\section{METODE}

Penelitian ini merupakan sebuah penelitian kuantitatif dengan pendekatan Asosiatif. Tempat dan Waktu Penelitian. Adapun tempat penelitian ini adalah di kampus Universitas Pamulang.

Adapun waktu penelitian yang dilakukan terhitung selama 4 bulan yakni sejak Mei-Agustus 2020. Penelitian ini dilakukan dengan bertahap mulai dari persiapan proposal judul penelitian, seminar proposal, penyempurnaan materi, pembuatan instrumen, pengumpulan data primer dan sekunder, penyebaran kuisioner, pengolahan data yang telah didapat oleh penulis dan penyusunan hasil, skripsi. Kegiatan penelitian dapat dilihat pada tabel berikut:C. Metode Analisis Data. 
Populasi dalam penelitian ini adalah mahasiswa S1 Manajemen reguler B dan C Semester 4 dan 5 di Universitas Pamulang yang membeli dan mengkonsumsi Teh Botol Sosro di sekitar Universitas Pamulang.

Metode yang digunakan dalam pengambilan sampel adalah non Probability Sampling. NonProbability Sampling yaitu teknik pengambilan sampel yang tidak memberi peluang atau kesempatan sama bagi setiap unsure atau anggota populasi untuk dipilih menjadi sampel. Pengambilan sampel non probability penelitian ini adalah Insidental sampling.

\section{HASIL DAN PEMBAHASAN}

1. Uji Parsial (Uji t)

Pengaruh dari masing-masing variabel X1 (kualitas produk) dan X2 (harga) terhadap keputusan pembelian (Y) dapat dilihat dari arah tanda dan tingkat signifikasi (probabilitas) dimana semua variabel mempunyai arah yang positif dan berpengaruh signiifikan karena nilai signifikasi $<0,05$. Atau pada tabel dengan nilai signifikasi 0,05 maka diperoleh $\mathrm{t}$ tabel 1,6605 atau $=$ TINV $(0,05 ; 98)$.

a. Variabel Kualitas Produk

Dari hasil perhitungan di atas didapat nilai $t$ hitung sebesar 4,464 dan nilai $t$ tabel $1,985(4,464>1,6605)$ dengan nilai signifikan senilai $0,000<0,05$ sehingga Ho ditolak dan Ha diterima, yang menyatakan "kualitas produk berpengaruh secara signifikan terhadap keputusan pembelian Teh Botol Sosro pada mahasiswa Universitas Pamulang S1 Manajemen semester 4 dan 5 reguler B dan $C^{\prime \prime}$.

b. Variabel Harga

Dari hasil perhitungan di atas didapat nilai $\mathrm{t}$ hitung sebesar 2,438 dan nilai $t$ tabel sebesar 1,985 $(2,438>1,6605)$ dengan nilai signifikan 0,017 < 0,05 sehingga $\mathrm{Ho}$ ditolak dan $\mathrm{Ha}$ diterima, yang menyatakan "harga berpengaruh secara signifikan terhadap keputusan pembelian Teh Botol Sosro pada mahasiswa Universitas Pamulang S1 Manajemen semester 4 dan 5 reguler $B$ dan $C^{\prime \prime}$.

2. Uji Simultan (Uji F)

Dari hasil perhitungan diatas dapat diperoleh Fhitung $>$ Ftabel = 51,593>3,09 dengan signifikan sebesar 0,000 . Karena harga signifikasi kurang dari 0,05 menunjukkan bahwa nilai Fhitung yang diperoleh tersebut signifikan sehingga hipotesis nihil (Ho) ditolakdan hipotesis kerja (Ha) yang berbunyi "Pengaruh Kualitas Produk dan Harga terhadap Keputusan Pembelian Teh Botol Sosro pada Mahasiswa Universitas Pamulang" diterima. Dan "terdapat pengaruh Kualitas Produk dan Harga secara simultan terhadap Keputusan Pembelian Teh Botol Sosro pada mahasiswa Universitas Pamulang S1 Manajemen semester 4 dan 5 reguler B dan C.

Setelah dijelaskan hasil penelitian ini dan kemudian diinterprestasikan seberapa baik data tersebut dianalisis penelitian yang diangkat, terutama kemampuan dalam menjelaskan seberapa baik pengaruh kualitas produk dan harga terhadap eputusan pembelian. selanjutnya akan dilakukan pembahasan mengenai hasil temuan-temuan antar variabel yaitu:

1. Berdasarkan nilai rata-rata dalam tanggapan responden mengenai kualitas produk yaitu 89,61 atau jika dibulatkan menjadi 89,6. Berada di kategori indeks (77-102: Tinggi) dimana tanggapan responden terhadap kualiatas produk (X1) memiliki skala Tinggi, dilihat dari skor tertinggi 84,25 yaitu pada pertanyaan "Teh Botol Sosro adalah minuman yang sangat mudah didapatkan".

2. Berdasarkan nilai rata-rata dalam tanggapan responden mengenai harga yaitu 79,25 atau jika dibulatkan menjadi 79,2 . Berada di kategori indeks (77-102: Tinggi) dimana tanggapan responden terhadap harga (X2) memiliki skala Tin 
ggi, dilihat dari skor tertinggi 79,25 yaitu pada salah satu dari tiga skala yang sama yaitu pertanyaan "Harga Teh Botol Sosro terjangkau dengan tipe mahasiswa seperti saya".

3. Berdasarkan nilai rata-rata dalam tanggapan responden mengenai keputusan pembelian yaitu 94,37 atau jika dibulatkan menjadi 94,40. Berada di kategori indeks (77-102: Tinggi) dimana tanggapan responden terhadap harga (X2) memiliki skala Tinggi, dilihat dari skor tertinggi 75,25 yaitu pada pertanyaan "Saya akan merekomendasikan Teh Botol Sosro kepada orang lain". Sehingga banyak responsen yang memilik Teh Botol Sosro karena produk Teh Botol Sosro sangat tepat jika direkomendasikan kepada orang lain

4. Berdasarkan hasil statistik dapat diketahui bahwa pengaruh kualitas produk (X1) dan harga (X2) terhadap keputusan pembelian (Y) adalah 0,515 atau sebesar 51\%. Hal ini berarti variabel-variabel independen (kualitas produk dan harga) berpengaruh terhadap variabel dependen sebesar 51\% sedangkan sisanya dipengaruhi faktor lain sebesar $49 \%$ diluar penelitian ini.

\section{KESIMPULAN}

Berdasarkan rumusan masalah pertama maka Kualitas Produk memiliki pengaruh yang positif dan signifikan terhadap keputusan pembelian dimana diperoleh nilai $t$ hitung $>t$ tabel $(4,464>1,6605)$ dan sig $<0,05(0,000<0,05)$.

Berdasarkan rumusan masalah kedua maka Harga memiliki pengaruh yang positif dan signifikan terhadap keputusan pembelian dimana diperoleh nilai $t$ hitung $>t$ tabel $(2,438>1,6605)$ dan sig $<0,05(0,017<0,05)$.

Berdasarkan rumusan masalah ketiga maka Kualitas Produk dan Harga memiliki pengaruh yang positif dan signifikan terhadap keputusan pembelian dimana diperoleh nilai $\mathrm{F}$ hitung $>\mathrm{F}$ tabel $(51,593>3,09)$ dan sig $<0,05 \quad(0,000<0,05)$.
Variabel independen berpengaruh terhadap variabel dependen sebesar $51 \%$ sedangkan sisanya sebesar $49 \%$ dipengaruhi oleh variabel lain diluar penelitian ini.

\section{DAFTAR PUSTAKA}

Albert, K. (2010). Belajar Mudah SPSS Untuk Pemula. Yogyakarta: Media Kom Amstrong., \& Kotler. (1997). DasarDasar Pemasaran Edisi Ke-7. Jakarta:

Amstrong., \& Kottler. (1997). Prinsipprinsip manajemen. Jakarta: Erlangga Augusty,F. (2006). Metode Penelitian Manajemen. Semarang: Badan

Erlangga, H. (2020). The Challenges of Organizational Communication in the Digital Era. Solid State Technology, 63(4), 1240-1246.

Hadi, S. (1991). Metodologi Research. Yogyakarta: Andi Offset

Haque, MG., Munawaroh, Sunarsi, D., (2020). Analysis of SMEs Culinary Marketing Strategy During Covid 19 Pancemic: A Study at "Sate Bebek Cilegon" Resto in Cilegon, Banten. International Journal of Education, Information Technology, and Others. Vol.3. Issue 2

Harga terhadap Keputusan Pembelian Rokok Surya (Studi Kasus pada konsumen Rokok Surya di UNSLA). Jurnal Penelitian Ekonomi dan Akutansi: Fakultas Ekonomi, 3(1). ISSN: 25023764.

Igir Friani, G. \& Tampi., Jhony R.E. \& Taroreh, H. (2018). Pengaruh Kualitas Produk dan Harga terhadap Keputusan Pembelian Mobil Daihatsu Grand Max Pick Up (Study pada PT.Astra Internasional Tbk Daihatsu Cabang Malalayang). Jurnal Administrasi Mandiri: Jurusan Ilmu Administrasi Program Studi Administrasi Bisnis, 6(2).

Jasmani, J., Sutiman, S., \& Sunarsi, D. (2020). Analysis of the Effect of Prices, Promotions and Products on Purchase Interest Impacts on Consumer Satisfaction of VIVO Brand Mobile 
Phones in South Tangerang Region. Jurnal Ad'ministrare, 7(1), 73-82.

Kasmad, K., Mustakim, M., \& Sunarsi, D. (2020). Increasing Community School Interest Through Service Quality, Prices and Promotion in Vocational High Schools. Journal of Educational Science and Technology (EST), 6(2).

Kottler. (2002). Manajemen Pemasaran,Edisi Millenium, Jilid 2. Jakarta: PT.Prenhallindo

Maddinsyah, A., Hidayat, D., Juhaeri, J., Susanto, D., \& Sunarsi, D. (2020). Desain Formulasi Dan Implementasi Bisnis Strategik Dengan Pendekatan Business Model Canvas (BMC) Terintegrasi Kerangka Integrated Performance Management System (IPMS) Pada Koperasi Asperindo. Inovasi, 7(2), 67-76.

Morissan. (2012). Metode Penelitian Survey. Jakarta: Kencana Prenada Media Group

Muhtarom, A., \& Tommy Syahrizal,M. (2018). Pengaruh Kualitas Produk dan Penerbit Universitas Diponegoro Ghozali, I. (2011). Aplikasi Analisis Multivariate Dengan Program SPSS. PT.Prenhallindo

Nurjaya, N., Affandi, A., Erlangga, H., Sunarsi, D., \& Jasmani, J. (2021). The Effect of Product Promotion and Innovation Activities on Marketing Performance in Middle Small Micro Enterprises in Cianjur. Budapest International Research and Critics Institute (BIRCI-Journal): Humanities and Social Sciences, 4(1), 528-540.

Putranto, I., \& Kartoni. (2020). Pengaruh Kualitas Produk dan Harga terhadap Keputusan Pembelian Tupperware (Studi kasus ibu rumah tangga di perumahan Kunciran, Tangerang). Jurnal Mandiri: Ilmu Pengetahuan, Seni, dan Teknologi, 4(1), 94-104. ISSN: 25890-3220. Semarang: Badan Penerbit
Sobarna, A., Rizal, R. M., Hambali, S., \& Sunarsi, D. (2020). Influence Make a Match Model toward Communication skills in Physical and Health Pedagogical Concept. Solid State Technology, 63(6), 1355-1363.

Sugiyono. (2012). Metode Penelitian Kuantitatif, Kualitatif dan RED. Bandung: PT. Alfabet

Sugiyono. (2013). Metode Penelitian Kuantitatif, Kualitatif dan RED. Bandung: PT. Alfabet

Sugiyono. (2015). Metode Penelitian Kuantitatif, Kualitatif dan RED. Bandung: PT. Alfabet

Sugiyono. (2016). Metode Penelitian Kuantitatif, Kualitatif dan RED. Bandung: PT. Alfabet

Sunarsi, D. (2020). Pengaruh Bauran Pemasaran Dan Kualitas Pelayanan Terhadap Kepuasan Konsumen Pada Giant Dept Store Cabang BSD Tangerang. E-Mabis: Jurnal Ekonomi Manajemen dan Bisnis, 21(1).

Swasta,B., \& Irawan. (2001). Manajemen Pemasaran Modern. Yogyakarta: Liberty Universitas Diponegoro

Syobar, K., Hardiyan, A., Romlah, O. Y., Yusup, M., \& Sunarsi, D. (2020). The Effect of Service Quality and Price on Purchase Decisions in Woodpecker Coffee in South Jakarta. Solid State Technology, 63(6), 1491-1504.

Yusuf Dana Mukti, M. (2015). Pengaruh Kualitas Produk dan Harga terhadap Keputusan Pembelian (Studi Kasus pada Mebel CV Jati Endah Lodoyo Blitar). Riset Mahasiswa Ekonomi:RITMIK, 2(1). ISSN: 24072680.

Yusuf, A., \& Sunarsi, D. (2020). The Effect of Promotion and Price on Purchase Decisions. Almana: Jurnal Manajemen dan Bisnis, 4(2), 272-279. 